\title{
ICES Journal of
}

\section{Introduction}

\section{Contribution to the Themed Section: 'Marine Aquaculture in the Anthropocene' Introduction}

\section{The future is now: marine aquaculture in the anthropocene}

\author{
Fabrice Pernet (1D ${ }^{1 *}$ and Howard I. Browman ${ }^{2}$ \\ ${ }^{1}$ Univ Brest, Ifremer, CNRS, IRD, LEMAR, Plouzané F-29280, France \\ ${ }^{2}$ Institute of Marine Research, Ecosystem Acoustics Group, Austevoll Research Station, Saugeneset 16, Storebø 5392, Norway \\ *Corresponding author: tel: 3329822 46 37; e-mail: Fabrice.Pernet@ifremer.fr.
}

Pernet, F. and Browman, H. I. The future is now: marine aquaculture in the anthropocene. - ICES Journal of Marine Science, 78: $315-$ 322.

Received 5 December 2020; accepted 14 December 2020; advance access publication 26 February 2021.

Aquaculture now produces more seafood than wild capture fisheries and this production is expected to at least double by 2050 . Representing almost half of global production, marine aquaculture will contribute to sustainably feeding the growing humanity. However, climate change will undoubtedly challenge the future growth of marine aquaculture. Temperature and sea-level rise, shifts in precipitation, freshening from glacier melt, changing ocean productivity, and circulation patterns, increasing occurrence of extreme climatic events, eutrophication, and ocean acidification are all stressors that will influence marine aquaculture. The objective of this themed article set was to bring together contributions on the broad theme of the potential impacts, adaptation, and mitigation strategies of marine aquaculture to climate change. Here we present 14 papers covering a diverse set of approaches including experimentation, modelling, meta-analysis and review, and disciplines like biology, ecology, economics, and engineering. These articles focus on the impacts of climate change-related stressors on the aquaculture potential itself and on the resulting ecological interactions (e.g. parasitism and predation), on phenotypic plasticity and adaptation potential of species, and on measures to mitigate the effects of climate change on aquaculture and vice versa. Considering this, adaptation of the aquaculture sector relies on anticipating the biogeographical changes in the distribution of species, determining their potential for adaptation and selective breeding for resistance or tolerance to climate-induced stressors, and fostering ecosystem resilience by means of conservation, restoration, or remediation. By will or by force, aquaculture will contribute to the low carbon economy of tomorrow. Aquaculture must move towards a new paradigm where the carbon footprint and the analysis of the life cycle of products are at least as important as economic profitability.

Keywords: adaptation, bivalve, blue economy, carbon, climate change, marine diseases, mitigation, ocean acidification, plasticity, salmon, seaweed, sustainability

\section{Introduction}

Officially, Earth is still in the Holocene epoch, which began around 11700 years ago after the last ice age. This epoch benefitted from stable and mild conditions particularly favourable to the expansion of Homo sapiens, which appeared 300000 years ago. The rapid increase in the human population and the concomitant explosion of agriculture and industry have altered biogeochemical carbon and nutrient cycles, landscapes, and the global climate. The environmental effect of human activity is increasing at unprecedented rates and at a global scale. At a conference in Mexico in 2000, Paul Crutzen, winner of the Nobel Prize in Chemistry, expressed the idea that we have entered a new geological epoch driven by the impact of human activities on the Earth System: the Anthropocene (Crutzen and Stoermer, 2000; Crutzen, 2002; Steffen et al., 2011).

Aquaculture is one of the human activities that accelerated greatly during the latter half of the last century (FAO, 2018a, 

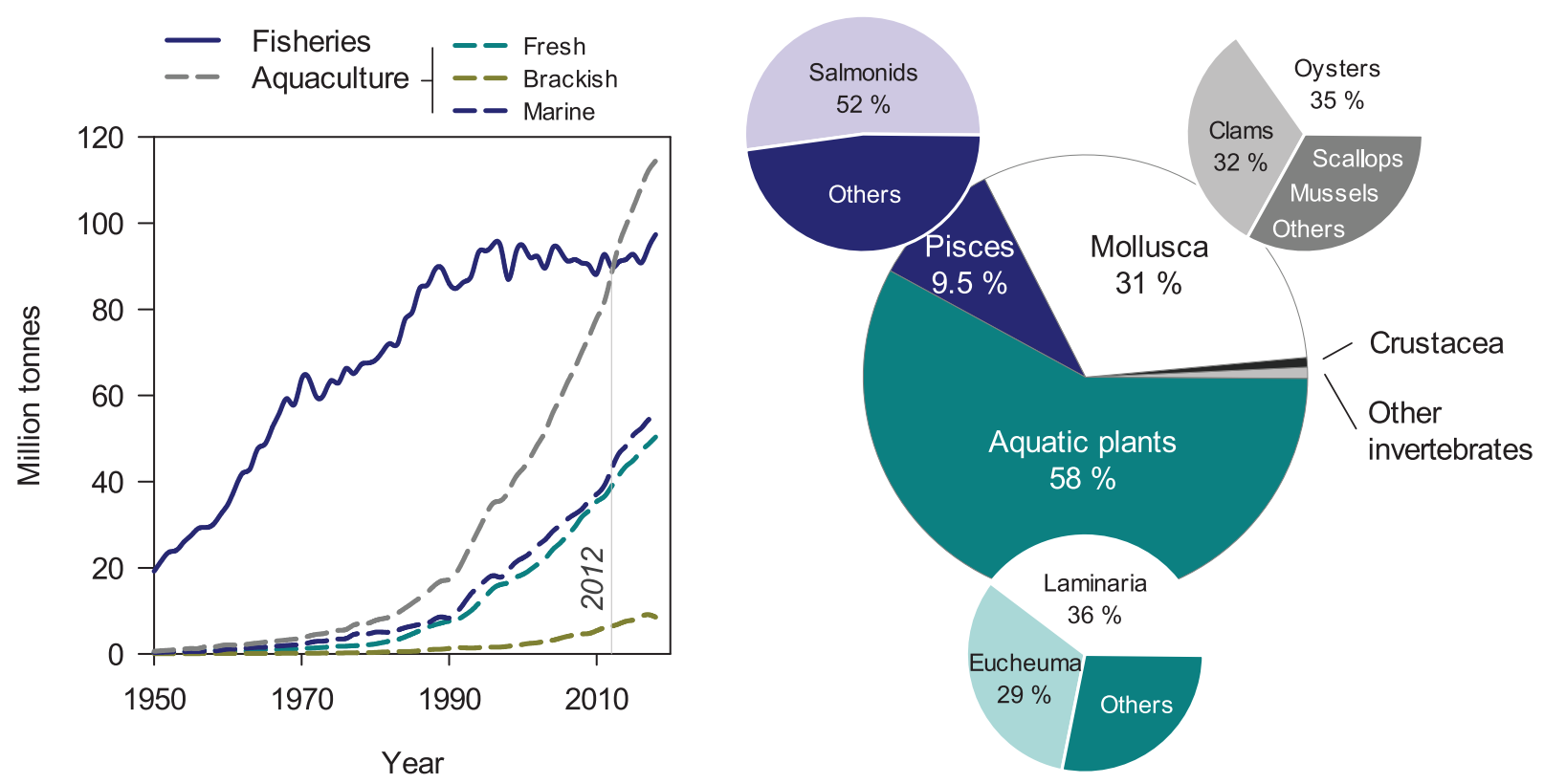

Figure 1. Expansion of global capture fisheries and aquaculture production from 1950 to 2018 (left) and partitioning of marine aquaculture production into taxonomic groupings in 2018 (right). Data are from FAO (2020).

Figure 1). Compared to terrestrial crop and livestock production, aquaculture was the fastest growing food sector for the period 19902009 (Troell et al., 2014) and production will continue to grow to meet rising demand (World Bank, 2013; FAO, 2018a). Marine aquaculture, which is focused mainly on aquatic plants, molluscs, and to a lesser extent fish, now accounts for almost half of global aquaculture production, recently exceeding wild capture fisheries (FAO, 2018a, Figure 1). However, climate change and other constraints will undoubtedly challenge future growth of marine aquaculture (Froehlich et al., 2018). Temperature and sea-level rise, shifts in precipitation, freshening from glacier melt, changing ocean productivity and circulation patterns, increasing occurrence of extreme climatic events, eutrophication, and ocean acidification (OA) are some of the stressors that will influence the potential of marine aquaculture production (FAO, 2018b; IPCC, 2019). It is, therefore, critical to anticipate new opportunities and challenges in marine aquaculture production during the anthropocene.

In this context, the ICES Journal of Marine Science (IJMS) solicited contributions to the themed article set (TS), "Marine aquaculture in the Anthropocene". The objective of this TS was to bring together contributions on the broad theme of the potential impacts, adaptation, and mitigation strategies of marine aquaculture in an era of rapid change.

In the call for papers, we solicited contributions on the following topics, among others:

- Impacts of climate change-related factors (warming, acidification, hypoxia, shifts in primary production, to name a few) on aquaculture production and spatial distribution of speciesspecific aquaculture activities.

- Phenotypic plasticity and adaptation potential of farmed species under climate change, including selective breeding for resilience.

- Impacts and adaptive measures to the increasing occurrence of extreme climatic events like storms and flooding (e.g. physical destruction of aquaculture facilities, escapes, disease spread).
- Climate change as an additional stressor, reinforcing other impacts such as pollution, disease outbreak, and biodiversity loss.

- Indirect impacts of climate change on marine aquaculture (via impacts on aquafeed supplies, on pest and disease emergences and biodiversity).

- Social and economic impacts of climate change on marine aquaculture.

- Vulnerability assessment and development of successful adaptations in local populations.

- Adaptive measures for mitigating the impacts of climate change on marine aquaculture (marine policy and planning measures, research and development, farming practices, ecosystem approach to aquaculture).

- Contribution of aquaculture to climate change and mitigation/ remediation strategies (ecological and carbon footprints, life cycle assessment (LCA), blue growth initiative).

We particularly encouraged the submission of papers reporting complex experimental set ups and modelling approaches that expand from single to multiple drivers, from single organisms to ecosystems/farms, and from acclimation to adaptation. Inter- and trans-disciplinary work linking natural and social science, and economics in tackling effects of climate change were particularly welcome. Thirty manuscripts were submitted for consideration; 14 were accepted and appear in this TS.

\section{An overview of the contributions in this article theme set Impacts of climate change-related factors on aquaculture production and spatial distribution of species-specific aquaculture activities}

Human activities are estimated to have caused $\sim 1^{\circ} \mathrm{C}$ of global warming above pre-industrial levels (IPCC, 2018). Mean ocean 
surface temperature has increased since the 1970s at a rate of $0.11^{\circ} \mathrm{C}$ per decade (IPCC, 2019). Depending on the future emission scenario, the top $100 \mathrm{~m}$ of the ocean is projected to warm by about $0.6-2.0^{\circ} \mathrm{C}$ by 2100 (IPCC, 2019). The oceans are not only absorbing a large amount of heat, leading to ocean warming, but also about $25 \%$ of anthropogenic $\mathrm{CO}_{2}$ emissions (Le Quéré et al., 2018). Increasing $\mathrm{CO}_{2}$ concentrations in the atmosphere lower the $\mathrm{pH}$ of the oceans, a process referred to as OA (Caldeira and Wickett, 2003; Orr et al., 2005). The $\mathrm{pH}$ in the ocean's surface waters has already decreased by 0.1 units since the beginning of the Anthropocene. According to recent projections, an additional decrease is expected by 2100 , ranging from 0.06 to 0.32 units, representing an increase in acidity of $15-110 \%$ (IPCC, 2019). Simultaneously, aqueous $\mathrm{CO}_{2}$ concentrations are increasing and carbonate ion concentrations $\left(\mathrm{CO}_{3}^{2-}\right)$ are decreasing, possibly impacting the growth, physiological rates, immune responses, behaviour, and survival of some marine organisms (e.g. Gazeau et al., 2013; Kroeker et al., 2013; Clements and Hunt, 2015 for reviews).

OA has been the most-studied single topics in marine science in recent times (Browman, 2016). Scientists have conducted many OA experiments, usually exposing organisms to experimental conditions based on scenarios modelled for oceanic waters, typically simulating present and near-future ocean $\mathrm{pCO}_{2}$ levels (Riebesell et al., 2011). However, most marine organisms are cultivated in coastal areas such as intertidal and upwelling zones, estuaries, fjords, and salt marshes where $\mathrm{pH} / \mathrm{pCO}_{2}$ levels vary far more dramatically than in the open ocean (e.g. Waldbusser and Salisbury, 2014; Vargas et al., 2017). Such variability in coastal environments limits the relevance of applying predictions of $\mathrm{CO}_{2}$ in the open ocean to these situations. Also, coastal aquaculture is likely to be affected by OA in different ways than open-ocean aquaculture (Clements and Chopin, 2017). Our knowledge of the variability in $\mathrm{pH}$ and carbonate chemistry in coastal areas is relatively poor and predictions are lacking. Saavedra et al. (2021) use time series of data from an instrument mooring and in situ sampling to characterize the variability in oceanographic conditions and the carbonate system at three bivalve aquaculture areas located along a latitudinal gradient off of the Humboldt Current System, Chile. Their results show $\mathrm{pH}_{\mathrm{T}}$ below 8 at most coastal sites, and occasionally below 7.5, reflecting upwelling events or freshwater runoff. Therefore, farmed bivalves are occasionally exposed to waters that are undersaturated in aragonite. The authors discuss the growth potential of bivalves along the latitudinal gradient and argue for considering high-resolution $\mathrm{pH} / \mathrm{pCO}_{2}$ time series and growth parameters of farmed bivalves to better anticipate the effects of climate change.

In bivalves, embryonic and larval development are generally sensitive to $\mathrm{OA}$, with reductions in size and survival of larvae and increases in the number of abnormal larvae (Gazeau et al., 2013). On an industrial scale, the most striking illustration of possible OA effects is the correlation between the $\mathrm{pH}$ of seawater and the survival of oyster larvae, clearly linking the $\mathrm{pH}_{\mathrm{T}} /$ $\mathrm{pCO}_{2}$ of seawater to hatchery failures (Barton et al., 2012). Espinel-Velasco et al. (2021) investigated how OA influenced settlement success in the New Zealand abalone, Haliotis iris. They examined direct effects of seawater $\mathrm{pH}_{\mathrm{T}}$ at the time of settlement, indirect effects of $\mathrm{pH}$ on settlement substrates made of crustose coralline algae (a calcifying organism susceptible to OA) and carryover effects by examining settlement in larvae reared to competency at ambient and reduced $\mathrm{pH}$. They found no direct or indirect effects, but nearly significant carryover effects with lower settlement in larvae reared at reduced $\mathrm{pH}_{\mathrm{T}}$. This study emphasizes the species-specific response to OA and also the importance of carryover effects for aquaculture operations such as spatfall collection.

\section{Phenotypic plasticity and adaptation potential of farmed species under climate change, including selective breeding for resilience}

Carryover effects can occur between development stages, but also between generations (intergenerational effects). For instance, exposure of adults to OA can produce positive or negative carryover effects in their progeny that influences survival under conditions of lower pH (e.g. Parker et al., 2012; Dupont et al., 2013). Clements et al. (2021) tested whether parental exposure to low $\mathrm{pH}$ influences reproductive conditioning and early larval development in eastern oysters Crassostrea virginica. They found that reduced $\mathrm{pH}_{\mathrm{NBS}}$ (7.5-7.7) increased the rate of reproductive development in both males and females but did not produce intergenerational effects. They also found that low $\mathrm{pH}$ conditions during early development resulted in higher larval survival, reduced shell height, and increased shell deformities. They suggest that the positive effects of low $\mathrm{pH}$ on oyster larvae could reflect local adaptation to lower $\mathrm{pH}$ conditions due to the geographical proximity of the oyster rearing sites to peat bogs.

Although a growing body of literature documents negative effects of acidification on marine organisms, the majority of this work has focused on the effects of future conditions on current populations, ignoring the potential effects of adaptation (e.g. Kelly and Hofmann, 2013; Bitter et al., 2019). Adaptation to OA will ultimately depend on trade-offs that occur when a relationship between two traits prevents them from being simultaneously optimized. For example, a population might possess genetic variation for tolerance to both OA and disease, but if there is a negative correlation between these two traits it may not be possible to evolve substantially increased tolerance to OA and disease simultaneously. Nordio et al. (2021) investigated whether adaption to OA results in evolutionary trade-offs with Vibrio spp. resistance. $\mathrm{OA}$ and pathogenic Vibrio spp. bacteria both have adverse impacts on the aquaculture production of the Pacific oyster Crassostrea gigas in the NE Pacific Ocean (Elston et al., 2008; Barton et al., 2012). They estimated the heritability of survival to a Vibrio harveyi infection and larval shell length under OA and normal conditions in oyster larvae. They found moderate heritability of survival to $V$. harveyi challenge and low heritability for shell length in low $\mathrm{pH}$ and normal conditions. Interestingly, the estimated breeding values do not correlate between larval shell size in OA conditions and survival to $V$. harveyi, suggesting that genetic selection of oysters for increased resistance to pathogenic $V$. harveyi is unlikely to impact larval sensitivity to OA. Finally, they found that estimated breeding values for larval shell length are correlated between $\mathrm{OA}$ and normal conditions, indicating larger larvae tend to do better in low $\mathrm{pH}$ seawater. The authors suggest that selection for larger larvae during culling could explain why hatchery oyster populations are less sensitive to OA than wild animals. This study emphasizes the need to investigate the evolutionary potential of marine animals to multiple climate change-related drivers (Riebesell and Gattuso, 2015; Boyd et al., 2018). 


\section{The effect of climate change-related drivers on species interactions: the intricate cases of parasitism and predation}

Climate change can alter host-pathogen interactions and, therefore, the likelihood of disease outbreaks (e.g. Harvell et al., 1999; Burge et al., 2014 for reviews). For instance, interactions between hosts, pathogens, and the environment govern disease outbreaks, and a change in any of these components can shift the balance towards or away from a high-intensity disease state (Burge et al., 2014). Temperature is the most well-studied climate-related driver of marine disease because it profoundly influences host and pathogen metabolism. Although there are reports of the exacerbating effects of temperature on the risk of disease, it is difficult to attribute a causal link between climate change and the occurrence of disease. Shephard and Gargan (2021) investigated the interaction between climate forcing and parasite infestation by sea lice Lepeophtheirus salmonis from coastal aquaculture on returns of wild Atlantic salmon Salmo salar to their natal river. The authors analysed annual counts of returning fish from Irish rivers, with or without (= the control) nearby salmon aquaculture. The authors show that salmon returns are decreasing over the long term and are negatively impacted by sea lice infestations associated with aquaculture. They also report a negative relationship between salmon returns in control rivers and climate (NAO effect), suggesting that these fish prefer lower temperatures during marine migration, with evidence of negative impacts from ocean warming. This NAO effect interacted with sea lice infestation: returns decreased with increased NAO, but only when lice infestation was low. The authors discuss the potential mechanisms underlying this complex interaction. This study emphasizes the need for long-term ecological studies examining the consequences of climate-disease interactions for developing management strategies, mitigating disease impacts, and preserving wild populations.

Salmon farms act as reservoirs of sea lice that are a source of transmission from farmed to wild salmon. Considering that temperature increases the epidemic potential of the parasite (Groner et al., 2014), Godwin et al. (2021) fit a Bayesian model for sea lice population dynamics and management to timeseries data of sea lice on farmed salmon in Pacific Canada and analysed the model under scenarios of warmer climate. They found that in hightemperature years current parasite control policy becomes ineffective as sea-louse abundance is expected to increase. Then, they simulated two alternative parasite management scenarios that rely on additional delousing treatments and observed that both would decrease louse counts on farms in high-temperature years. This study highlights the importance of policies designed to account for future environmental change (also see the next section).

Rapid increase in salmon farming has dramatically altered the disease dynamics between farmed and wild salmon (e.g. Krkosek et al., 2011; Vollset et al., 2018). In Norway, new restrictions on fish farming have been enforced in the south due to the impacts of sea lice on wild salmonids. In northern areas, the effects of pathogens on wild salmonids are lower, reflecting relatively low density of fish farms and low temperatures. However, both factors are now increasing. These areas contain habitats supporting some of the largest remaining wild salmonid populations in the world. Vollset et al. (2021) question how these populations will cope with the changes that are coming. They identify research questions emerging from these upcoming changes and discuss approaches and methods to address them. They conclude that policies related to spatial management of fish farming must consider uncertainties with respect to pathogen dynamics in the north until these research questions are fully addressed.

Temperature can differentially influence species within a community, significantly affecting the outcome of trophic interactions (e.g. O'Connor, 2009). For example, ocean warming is predicted to strengthen plant-herbivore interactions and potentially impact seaweed production. Warming increases the consumption rate of herbivores and also the palatability of macroalgae. This effect might be tempered by other factors such as nutrient availability. Endo et al. (2021) investigated the combined effects of ocean warming and nutrient enrichment on the consumption rate of the alga Undaria pinnatifida by the isopod Cymodocea japonica. They show no significant interaction between elevated temperature and nutrient enrichment on consumption rate, but there were additive effects. The consumption rate doubled in response to elevated temperature and nutrient enrichment and tripled when they were combined. Therefore, nutrient enrichment under warmer conditions is predicted to increase the risk of herbivory during the cultivation of this algal species.

\section{Adaptive measures for mitigating the impacts of climate change on marine resources}

The combined accelerated footprint of climate change and anthropogenic pressures on marine life raise the need for restoration programmes worldwide (Duarte et al., 2020). Rinkevich (2021) analyses the recent literature on coral reef restoration from an ecological engineering perspective, linking biology, ecology, and engineering to improve and rehabilitate damaged ecosystems. The author distinguishes ecological engineering applications that integrate all aspects of reef restoration and ecological engineering aspects that deal with assisted genetics, coral chimerism, aquaculture of reef living organisms and consideration of life cycle parameters of the transplanted species. The author emphasizes that the object of study is often the population and the community, and only more rarely the ecosystem. Finally, he concludes that ecological engineering should consider creating new ecosystems that did not exist before rather than seeking to recreate historic ecosystem states.

In a literature review, Daly et al. (2021) investigated the implications of phenotypic plasticity for enhancement of crustacean stocks. The main idea is that there are behavioural and morphological differences between hatchery-raised and wild individuals that reflect adaptive responses to an unnatural rearing environment, and this phenotypic plasticity could be used to improve stock enhancement. The authors examine how behavioural and morphological phenotypic plasticity can affect crustacean ecology and recommend consideration of this plasticity in release strategies through adjustments to rearing protocols.

\section{Sustainable development of aquaculture and its contribution to climate change}

Concerns over the footprint of the ever-expanding aquaculture industry have motivated a range of approaches focusing on aquaculture impact analysis. The concept of aquaculture carrying capacity, popularized in the 1990s (Chapman and Byron, 2018), is generally framed as the maximum aquaculture intensity an ecosystem can support within limits of an ecological and social change acceptable to stakeholders (McKindsey et al., 2006). Most 
studies have focused on the production and ecological components, ignoring the social perspective. Kluger and Filgueira (2021) argue that carrying capacity should be viewed as multidimensional, iterative, inclusive, and just. Hence, the scope of carrying capacity needs to move from industry-driven towards an inclusive vision taking into consideration historical, cultural, and socio-economic concerns of all stakeholders. The authors suggest guidelines to frame a safe operating space for aquaculture based on a multi-criterion, multi-stakeholder approach, while embracing the social-ecological dynamics of aquaculture settings by applying an adaptive approach and acknowledging the critical role of place-based constraints. Carrying capacity approaches should proactively engage with aquaculture-produced outcomes at multiple scales, embracing interdisciplinarity, complexity, and uncertainty. This study highlights the necessity of scoping carrying capacity with the voices of all relevant societal groups, before aquaculture implementation, to jointly develop sustainable aquaculture.

The cultivation and use of seaweeds have high potential to support sustainable jobs and growth, providing biomass for human food, animal feed, and other applications like climate remediation. Although the large majority of seaweed production is located in Asia, interest in Europe is on the rise. van den Burg et al. (2021) show that, from a people, planet and profit perspective, the focus is not on producing large volumes of seaweed but on producing the right amount of the right seaweeds, considering the carrying capacity of European seas. They argue that the seaweed sector must avoid developing along the path of traditional economies (i.e. cost-driven decisions) but rather develop in a manner consistent with the emerging circular blue economy. Seaweeds should not be seen as a new product added to the market but become an integral part of the European food system, being used for human consumption, animal feed, and for improving food production processes.

Thomas et al. (2021) conducted an environmental LCA of a kelp farm in Sweden. The LCA includes spore production, seeding lines, cultivation at sea, harvesting and preservation and accounts for nutrient bioremediation and carbon capture. They compared two seeding techniques (submersion and spray) and four preservation methods (hang-drying outdoors, heated aircabinet drying, ensilage, and freezing). The authors found that more nutrients and carbon are absorbed than emitted by the seaweed supply chain. Emissions are most affected by preservation method. The largest impact results from freezing and air-cabinet drying, the two most energy-consuming processes, followed by the cultivation infrastructure. Hatchery processes, harvesting and the ensilage and hang-drying outdoors have relatively small impacts. This study highlights the relevance of LCA to marine aquaculture (Bohnes et al., 2019) and emphasizes the potential of seaweed aquaculture as a solution to mitigate eutrophication and climate change (Froehlich et al., 2019).

Finally, Froehlich et al. (2021) ask how the 20 International Council for the Exploration of the Sea (ICES) member nations will sustainably meet the increasing demand for seafood, considering that the majority of these nations have not developed robust aquaculture industries. They evaluated past trends in farmed and wild seafood production and consumption in ICES nations, and the potential and need to increase aquaculture production by 2050. They found that the majority of ICES nations lack longterm strategies for aquaculture, with few plans accounting for climate change and an increasing gap between future production and consumption. This work highlights the need to prioritize aquaculture policy to set more ambitious domestic production goals and improve sustainable sourcing of seafood from other parts of the world, with a more explicit incorporation of climate change into decision-making.

\section{Summary and forward look}

We hope that the articles in this TS will be seen as a small step forward in supporting a better understanding of the challenges and potential of "marine aquaculture in the Anthropocene".

As is clear from the preceding, this TS attracted a very diverse set of articles in terms of the approaches taken (experimentation, modelling, meta-analysis, review) and the disciplines covered (biology, economics, engineering), reflecting the complexity of the topic.

The call for papers solicited submissions that used approaches ranging from a single to multiple drivers, a single organism to an ecosystem, and acclimatization to adaptation. Indeed, these approaches are essential for understanding the effects of climate change and providing guidelines to policymakers (Riebesell and Gattuso, 2015). The research articles that we received were generally multi-factorial (Endo et al., 2021; Espinel-Velasco et al., 2021; Godwin et al., 2021; Nordio et al., 2021; Shephard and Gargan, 2021) and several address adaptation issues (Clements et al., 2021; Espinel-Velasco et al., 2021; Nordio et al., 2021). However, they focus on the species of interest and pay relatively little attention to other ecosystem components. This reflects the slow uptake of ecosystem-based aquaculture (Brugère et al., 2019). The exception was pathogens and parasites (Godwin et al., 2021; Nordio et al., 2021; Shephard and Gargan, 2021; Wiik Vollset et al., 2021), probably because they pose major challenges to aquaculture production. The change of scale from single organism to ecosystem remains a daunting challenge.

Inter- and trans-disciplinary work linking natural and social science, and economics, in tackling effects of climate change on aquaculture were particularly welcome. Although taking a transdisciplinary approach is a key component of sustainability science (Hirsch Hadorn et al., 2006), we did not receive any transdisciplinary contributions. Work of this nature is still in its infancy.

From all these articles and the associated scientific literature, it seems that three types of action are possible for adapting aquaculture operations to climate change. First, we must anticipate the biogeographical changes in the distribution of species. Species are indeed distributed over geographic areas where physical and biotic conditions fit their physiological range (Pörtner, 2002), and any changes in these conditions may locally alter the potential for aquaculture production (Froehlich et al., 2018). Second, we must determine if species can adapt to a range of stressors via evolution. Then, the selection of robust phenotypes, which are resistant or tolerant to these stressors would be an option for the aquaculture industry, although trade-off with other traits and maintaining the genetic diversity need to be carefully considered (Reid et al., 2019; Tan et al., 2020). Third, we must consider ecosystem conservation, restoration or remediation strategies to foster resilience to climate change stressors. Biodiversity indeed limit disease risk (Keesing et al., 2010), an upcoming threat under climate change (Harvell et al., 1999). Macroalgae and plant act as a carbon sink and create local refugia against acidification for calcifying organisms (Groner et al., 2018; Young and Gobler, 2018). These examples suggest that the combination of species that 
interact favourably with each other can mitigate the effects of climate change. These three options are not mutually exclusive and should be considered together.

To limit the effects of climate change, human activities, including aquaculture, are currently being imposed new constraints. According to the Paris agreements signed by 196 government representatives in 2016, anthropogenic greenhouse gas emissions must decrease rapidly to keep the increase in global average temperature to well below $2^{\circ} \mathrm{C}$ by 2100 . This effort, which is based on limiting our consumption of fossil fuels, is promoting a lowcarbon economy. Aquaculture will have to adapt to this new standard. From this point of view, not all aquaculture productions are created equal. For example, intensive culture of shrimp or carnivorous fish is highly energy demanding, while production of omnivorous fishes, bivalve molluscs or macroalgae have a low or even negative carbon footprint (Cochrane et al., 2009). Therefore, aquaculture will undoubtedly contribute to the low carbon economy of tomorrow. Development choices should be based on carbon footprint and product LCAs in addition to traditional profitability analyses. Aquaculture can help make our planet great again, this is a matter of choice.

\section{Funding}

HIB's contribution to this article themed set was supported by Project \# 83741 ("Scientific publishing and editing") from the Institute of Marine Research, Norway. FP's contribution was supported by the "Aiaiai" project funded by Ministère de la Transition Ecologique et Solidaire (MTES) and Fondation pour la Recherche sur la Biodiversité (FRB), France.

\section{Acknowledgements}

We are grateful to the many authors who submitted their work for publication in this theme issue, and to the many more referees without whom science would collapse.

\section{Disclaimer}

The opinions and positions taken in this article are those of the authors and do not necessarily reflect those of their employers.

\section{References}

Barton, A., Hales, B., Waldbusser, G. G., Langdon, C., and Feely, R. A. 2012. The Pacific oyster, Crassostrea gigas, shows negative correlation to naturally elevated carbon dioxide levels: implications for near-term ocean acidification effects. Limnology and Oceanography, 57: 698-710.

Bitter, M. C., Kapsenberg, L., Gattuso, J. P., and Pfister, C. A. 2019. Standing genetic variation fuels rapid adaptation to ocean acidification. Nature Communications, 10: 5821.

Bohnes, F. A., Hauschild, M. Z., Schlundt, J., and Laurent, A. 2019. Life cycle assessments of aquaculture systems: a critical review of reported findings with recommendations for policy and system development. Reviews in Aquaculture, 11: 1061-1079.

Boyd, P. W., Collins, S., Dupont, S., Fabricius, K., Gattuso, J. P., Havenhand, J., Hutchins David, A. et al. 2018. Experimental strategies to assess the biological ramifications of multiple drivers of global ocean change-a review. Global Change Biology, 24: 2239-2261.

Browman, H. I. 2016. Applying organized scepticism to ocean acidification research. ICES Journal of Marine Science, 73: 529-536.

Brugère, C., Aguilar-Manjarrez, J., Beveridge, M. C. M., and Soto, D. 2019. The ecosystem approach to aquaculture 10 years on-a critical review and consideration of its future role in blue growth. Reviews in Aquaculture, 11: 493-514.
Burge, C. A., Mark Eakin, C., Friedman, C. S., Froelich, B., Hershberger, P. K., Hofmann, E. E., Petes, L. E., et al. 2014. Climate change influences on marine infectious diseases: implications for management and society. Annual Review of Marine Science, 6: 249-277.

Caldeira, K., and Wickett, M. E. 2003. Anthropogenic carbon and ocean $\mathrm{pH}$. Nature, 425: 365-365.

Chapman, E. J., and Byron, C. J. 2018. The flexible application of carrying capacity in ecology. Global Ecology and Conservation, 13: e00365.

Clements, J. C., Carver, C. E., Mallet, M. A., Comeau, L. A., and Mallet, A. L. 2021. $\mathrm{CO}_{2}$-induced low $\mathrm{pH}$ in an eastern oyster (Crassostrea virginica) hatchery positively affects reproductive development and larval survival but negatively affects larval shape and size, with no intergenerational linkages. ICES Journal of Marine Science, doi:10.1093/icesjms/fsaa089

Clements, J. C., and Chopin, T. 2017. Ocean acidification and marine aquaculture in North America: potential impacts and mitigation strategies. Reviews in Aquaculture, 9: 326-341.

Clements, J. C., and Hunt, H. L. 2015. Marine animal behaviour in a high CO2 ocean. Marine Ecology Progress Series, 536: 259-279.

Cochrane, K., De Young, C., Soto, D., and Bahri, T. 2009. Climate change implications for fisheries and aquaculture. FAO Fisheries and Aquaculture Technical Paper, 530: 212.

Crutzen, P., and Stoermer, E. 2000. The 'Anthropocene', IGPB Newsletter 41: 1-20.

Crutzen, P. J. 2002. Geology of mankind. Nature, 415: 23-23.

Daly, B. J., Eckert, G. L., and Long, W. C. 2021. Moulding the ideal crab: implications of phenotypic plasticity for crustacean stock enhancement. ICES Journal of Marine Science, doi: 10.1093/icesjms/fsaa043

Duarte, C. M., Agusti, S., Barbier, E., Britten, G. L., Castilla, J. C., Gattuso, J.-P., Fulweiler, R. W. et al. 2020. Rebuilding marine life. Nature, 580: 39-51.

Dupont, S., Dorey, N., Stumpp, M., Melzner, F., and Thorndyke, M. 2013. Long-term and trans-life-cycle effects of exposure to ocean acidification in the green sea urchin Strongylocentrotus droebachiensis. Marine Biology, 160: 1835-1843.

Elston, R. A., Hasegawa, H., Humphrey, K. L., Polyak, I. K., and Hase, C. C. 2008. Re-emergence of Vibrio tubiashii in bivalve shellfish aquaculture: severity, environmental drivers, geographic extent and management. Diseases of Aquatic Organisms, 82: $119-134$.

Endo, H., Sato, Y., Kaneko, K., Takahashi, D., Nagasawa, K., Okumura, Y., and Agatsuma, Y. 2021. Ocean warming combined with nutrient enrichment increases the risk of herbivory during cultivation of the marine macroalga Undaria pinnatifida. ICES Journal of Marine Science, doi:10.1093/icesjms/fsaa069

Espinel-Velasco, N., Lamare, M., Kluibenschedl, A., Moss, G., and Cummings, V. 2021. Ocean acidification induces carry-over effects on the larval settlement of the New Zealand abalone, Haliotis iris. ICES Journal of Marine Science, doi: 10.1093/icesjms/fsaa086

FAO. 2018a. The State of World Fisheries and Aquaculture (SOFIA) Meeting the Sustainable Development Goals, Food and Agriculture Organization, Rome, Italy p. xiii +210 .

FAO. 2018b. Impacts of Climate Change on Fisheries and Aquaculture: Synthesis of Current Knowledge, Adaptation and Mitigation Options. FAO Fisheries and Aquaculture Technical Paper, Rome, $627 \mathrm{pp}$.

FAO. 2020. Fishery and Aquaculture Statistics. Global production by production source 1950-2018 (FishstatJ). In: FAO Fisheries and Aquaculture Department. Rome. Updated 2020. www.fao.org/fish ery/statistics/software/fishstatj/en (last accessed 20 October 2020).

Froehlich, H., Couture, J., Falconer, L., Krause, G., Morris, J., Pérez, M., Stentiford, G. et al. 2021. Mind the gap between ICES nations' 
future seafood consumption and aquaculture production. ICES Journal of Marine Science, 10.1093/icesjms/fsaa066

Froehlich, H. E., Afflerbach, J. C., Frazier, M., and Halpern, B. S. 2019. Blue growth potential to mitigate climate change through seaweed offsetting. Current Biology, 29: 3087-3093.e3.

Froehlich, H. E., Gentry, R. R., and Halpern, B. S. 2018. Global change in marine aquaculture production potential under climate change. Nature Ecology \& Evolution, 2: 1745-1750.

Gazeau, F., Parker, L., Comeau, S., Gattuso, J.-P., O'Connor, W., Martin, S., Pörtner, H.-O. et al. 2013. Impacts of ocean acidification on marine shelled molluscs. Marine Biology, 160: 2207-2245.

Godwin, S. C., Krkošek, M., Reynolds, J. D., and Bateman, A. W. 2021. Sea-louse abundance on salmon farms in relation to parasite-control policy and climate change. ICES Journal of Marine Science, doi: 10.1093/icesjms/fsaa173.

Groner, M. L., Burge, C. A., Cox, R., Rivlin, N. D., Turner, M., Van Alstyne, K. L., Wyllie-Echeverria, S. et al. 2018. Oysters and eelgrass: potential partners in a high $\mathrm{pCO}(2)$ ocean. Ecology, 99: 1802-1814.

Groner, M. L., Gettinby, G., Stormoen, M., Revie, C. W., and Cox, R. 2014. Modelling the impact of temperature-induced life history plasticity and mate limitation on the epidemic potential of a marine ectoparasite. PLoS One, 9: e88465.

Harvell, C. D., Kim, K., Burkholder, J. M., Colwell, R. R., Epstein, P. R., Grimes, D. J., Hofmann, E. E. et al. 1999. Review: marine ecology-emerging marine diseases-climate links and anthropogenic factors. Science, 285: 1505-1510.

Hirsch Hadorn, G., Bradley, D., Pohl, C., Rist, S., and Wiesmann, U. 2006. Implications of transdisciplinarity for sustainability research. Ecological Economics, 60: 119-128.

IPCC. 2018. Summary for Policymakers. p. 32. Ed. by V. Masson-Delmotte, P. Zhai, H. O. Pörtner, D. Roberts, J. Skea, P. R. Shukla, A. Pirani, W. Moufouma-Okia, C. Péan, R. Pidcock, S. Connors, J. B. R. Matthews, Y. Chen, X. Zhou, M. I. Gomis, E. Lonnoy, T. Maycock, M. Tignor, and T. Waterfield. World Meteorological Organization, Geneva, Switzerland.

IPCC. 2019. IPCC Special Report on the Ocean and Cryosphere in a Changing Climate [H.-O. Pörtner, D.C. Roberts, V. Masson-Delmotte, P. Zhai, M. Tignor, E. Poloczanska, K. Mintenbeck, A. Alegriá, M. Nicolai, A. Okem, J. Petzold, B. Rama, N.M. Weyer (eds.) ]. In press.

Keesing, F., Belden, L. K., Daszak, P., Dobson, A., Harvell, C. D., Holt, R. D., Hudson, P. et al. 2010. Impacts of biodiversity on the emergence and transmission of infectious diseases. Nature, 468: 647-652.

Kelly, M. W., and Hofmann, G. E. 2013. Adaptation and the physiology of ocean acidification. Functional Ecology, 27: 980-990.

Kluger, L. C., and Filgueira, R. 2021. Thinking outside the box: embracing social complexity in aquaculture carrying capacity estimations. ICES Journal of Marine Science, 10.1093/icesjms/fsaa063

Krkosek, M., Connors, B. M., Morton, A., Lewis, M. A., Dill, L. M., and Hilborn, R. 2011. Effects of parasites from salmon farms on productivity of wild salmon. Proceedings of the National Academy of Sciences of the United States of America, 108: 14700-14704.

Kroeker, K. J., Kordas, R. L., Crim, R., Hendriks, I. E., Ramajo, L., Singh, G. S., Duarte, C. M. et al. 2013. Impacts of ocean acidification on marine organisms: quantifying sensitivities and interaction with warming. Global Change Biology, 19: 1884-1896.

Le Quéré, C., Andrew, R. M., Friedlingstein, P., Sitch, S., Hauck, J., Pongratz, J., Pickers, P. A. et al. 2018. Global carbon budget 2018. Earth System Science Data, 10: 2141-2194.

McKindsey, C. W., Thetmeyer, H., Landry, T., and Silvert, W. 2006. Review of recent carrying capacity models for bivalve culture and recommendations for research and management. Aquaculture, 261: 451-462.

Nordio, D., Khtikian, N., Andrews, S., Bertotto, D., Leask, K., and Green, T. 2021. Adaption potential of Crassostrea gigas to ocean acidification and disease caused by Vibrio harveyi. ICES Journal of Marine Science, doi:10.1093/icesjms/fsaa080

O'Connor, M. I. 2009. Warming strengthens an herbivore-plant interaction. Ecology, 90: 388-398.

Orr, J. C., Fabry, V. J., Aumont, O., Bopp, L., Doney, S. C., Feely, R. A., Gnanadesikan, A. et al. 2005. Anthropogenic ocean acidification over the twenty-first century and its impact on calcifying organisms. Nature, 437: 681-686.

Parker, L. M., Ross, P. M., O'Connor, W. A., Borysko, L., Raftos, D. A., and Pörtner, H. O. 2012. Adult exposure influences offspring response to ocean acidification in oysters. Global Change Biology, 18: 82-92.

Pörtner, H. O. 2002. Climate variations and the physiological basis of temperature dependent biogeography: systemic to molecular hierarchy of thermal tolerance in animals. Comparative Biochemistry and Physiology - Part A, 132: 739-761.

Reid, G. K., Gurney-Smith, H. J., Marcogliese, D. J., Knowler, D., Benfey, T., Garber, A. F., Forster, I. et al. 2019. Climate change and aquaculture: considering biological response and resources. Aquaculture Environment Interactions, 11: 569-602.

Riebesell, U., Fabry, V. J., Hansson, L., and Gattuso, J.-P. 2011. Guide to best practices for ocean acidification research and data reporting, Office for Official Publications of the European Communities.Luxembourg, pp. 258

Riebesell, U., and Gattuso, J.-P. 2015. Lessons learned from ocean acidification research. Nature Climate Change, 5: 12-14.

Rinkevich, B. 2021. Ecological engineering approaches in coral reef restoration. ICES Journal of Marine Science, doi:10.1093/icesjms/fsaa022

Saavedra, L. M., Saldías, G. S., Broitman, B. R., and Vargas, C. A. 2021. Carbonate chemistry dynamics in shellfish farming areas along the Chilean coast: natural ranges and biological implications. ICES Journal of Marine Science, doi:10.1093/icesjms/fsaa127

Shephard, S., and Gargan, P. 2021. Wild Atlantic salmon exposed to sea lice from aquaculture show reduced marine survival and modified response to ocean climate. ICES Journal of Marine Science, doi:10.1093/icesjms/fsaa079

Steffen, W., Grinevald, J., Crutzen, P., and McNeill, J. 2011. The Anthropocene: conceptual and historical perspectives. Philosophical Transactions of the Royal Society A: Mathematical, Physical and Engineering Sciences, 369: 842-867.

Tan, K., Zhang, H., and Zheng, H. 2020. Selective breeding of edible bivalves and its implication of global climate change. Reviews in Aquaculture, 12: 2559-2572.

Thomas, J.-B., Sodré Ribeiro, M., Potting, J., Cervin, G., Nylund, G., Olsson, J., Albers, E. et al. 2021. A comparative environmental life cycle assessment of hatchery, cultivation, and preservation of the kelp Saccharina latissima. ICES Journal of Marine Science, doi: 10.1093/icesjms/fsaal12

Troell, M., Naylor, R. L., Metian, M., Beveridge, M., Tyedmers, P. H., Folke, C., Arrow, K. J. et al. 2014. Does aquaculture add resilience to the global food system? Proceedings of the National Academy of Sciences of the United States of America, 111: 13257-13263.

van den Burg, S. W. K., Dagevos, H., and Helmes, R. J. K. 2021. Towards sustainable European seaweed value chains: a triple $\mathrm{P}$ perspective. ICES Journal of Marine Science, doi: 10.1093/icesjms/fsz183

Vargas, C. A., Lagos, N. A., Lardies, M. A., Duarte, C., Manríquez, P. H., Aguilera, V. M., Broitman, B. et al. 2017. Species-specific responses to ocean acidification should account for local adaptation and adaptive plasticity. Nature Ecology \& Evolution, 1: 0084.

Vollset, K. W., Qviller, L., Skår, B., Barlaup, B. T., and Dohoo, I. 2018. Parasitic sea louse infestations on wild sea trout: separating the roles of fish farms and temperature. Parasites \& Vectors, 11: 609.

Waldbusser, G. G., and Salisbury, J. E. 2014. Ocean acidification in the coastal zone from an organism's perspective: multiple system 
parameters, frequency domains, and habitats. Annual Review of Marine Science, 6: 221-247.

Wiik Vollset, K., Lennox, R., Davidsen, J., Eldøy, S., Isaksen, T. E., Madhun, A., Karlsson, S. et al. 2021. Wild salmonids are running the gauntlet of pathogens and climate as fish farms expand northwards. ICES Journal of Marine Science, doi:10.1093/icesjms/fsaa138
World Bank. 2013. Fish to 2030: prospects for fisheries and aquaculture. Agriculture and Environmental Services Discussion Paper 03, Washington, D.C., pp. 80

Young, C. S., and Gobler, C. J. 2018. The ability of macroalgae to mitigate the negative effects of ocean acidification on four species of North Atlantic bivalve. Biogeosciences, 15: 6167-6183. 